\title{
THE FACTORS AFFECTING THE ADOPTION OF DIGITAL PAYMENT SERVICES USING TRUST AS MEDIATING VARIABLE
}

\section{Florentina Kurniasari}

\author{
Universitas Multimedia Nusantara, Tangerang, Indonesia
}

\author{
Article Information \\ Received: 5 February 2021 \\ Accepted: 10 May 2021 \\ Published: 5 July 2021 \\ DOI: $10.33555 / \mathrm{embm} . v 8 \mathrm{i} 1.165$ \\ Corresponding Author: \\ Florentina Kurniasari \\ Tangerang, Indonesia \\ Email: florentina@umn.ac.id \\ ISSN $\quad 2338-8854$ \\ eISSN 2620-9918
}

\begin{abstract}
The advance of technology development today brings an innovation in the financial industries, especially in the sector of payment. The purpose of this research is to analyze the effect of personal innovativeness, security concerns and perceived enjoyment into customer adoption of digital payment services using trust as mediating variable. As a quantitative research, the study distributed questionnaires to 186 respondents who are customers who used digital payment platform in settling their business transactions. The data collection was furthered processed statistically using Structural Equation Method (SEM). The study showed that the customer decision to using the digital payment services had significantly influenced by trust variable, in which security concerns had the highest influence in creating the borrower's trust.
\end{abstract}

Keyword: Adoption, Enjoyment, Innovativeness, Security, Trust 


\section{Introduction}

The advancement in information and technology had a great impact in various business, including the financial industries. The ICT sector also growth tremendously in Indonesia. Latest data showed that there are $73.7 \%$ penetration of the internet from the total population of Indonesia that reached 266,91 million people in the end year 2020 . This internet user growth at $8.9 \%$ per year compare of the previous year with 196 million people are internet user and the majority of them $(56.4 \%)$ live in Java island (We Are Social \& Hootsuite, 2020).

The survey data conducted by Indonesia Survey Center (2020)) showed that 95.4\% internet users are connected through their smartphone and $97.1 \%$ heavily depend on the availability of data or quota from the internet provider.

The growth of ICT in Indonesia opened opportunity for new business especially online business that could be easily accessed via internet. Financial technology or fintech referred to the combination or collaboration of financial services with modern and innovative technology (Dorfleitner et al., 2017). Fintech was an alternative solution for the customers in settling various financial transactions. Fintech was a major program initiated by Indonesian government and stated in the Master Plan of Financial Sector (for the year 2020-2024) to increase financial inclusion in Indonesia. Fintech was successfully attracted the internet users because of its simplicity, efficient, cheap and offering many promotion (Daily Social, 2018). The registration process for having new account in fintech is simple by using the National Identity Card. All process will be handled digitally, so the customers did not need to visit the financial institution office to submit the documents. Fintechnews (2018) explained some category of fintech in Indonesia that is showed in Figure 1.

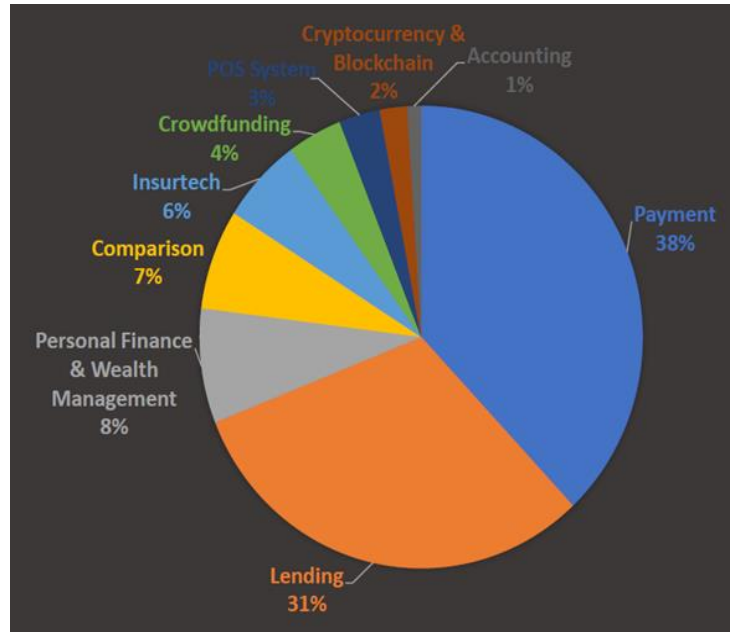

Figure 1. Fintech Distribution in Indonesia (in \%) Source: Fintechnews (2018)

The first category is related with the payment services using the digital platform such as GoPay, OVO, Doku, etc. Digital payment services had the highest contribution in the fintech industries in Indonesia $(38 \%)$. The second category is related with the lending services or peer-topeer lending $(31 \%)$, such as: Investree, KoinWorks, Modalku, etc. The next category is related with the digital personal finance and wealth management $(8 \%)$ such as: Finansialku, Stockbit, etc. The fourth category is coming from the market aggregator $(7 \%)$. This fintech model collected all related financial information so the users had a capability to make a comparison before making a financial decision. Cekaja, Atur Duit, etc. are the example of market aggregator fintech. The other form of fintech was the collaboration model between insurance services with the digital platform widely known as Insurtech (6\%), such as: Asuransiku, Cermati, etc. Kitabisa.com was the crowdfunding model that was used to collect donation of fund from some people through digital platform (4\%). There's another fintech model that was called as Point of Sales (3\%) like Moka, Pawoon, etc. The bitcoin platform such as Crypto \& Blockchain was another form of fintech $(2 \%)$. The latest category of fintech came from the Accounting platform that was useful in digital accounting recording and reporting (1\%). 
The digital payment services were the most popular platform in the Indonesia fintech model since it was easily used just by accessing the internet through the smartphone. There were many services offered to the customers including: transfer, paying the bills, top-up or paying the online transaction. Cashless payment became a major option for the customer in doing in the financial transaction (Katadata Insight Center, 2018). The following figure showed that $76.08 \%$ of Indonesian preferred using the electronic or cashless payment.

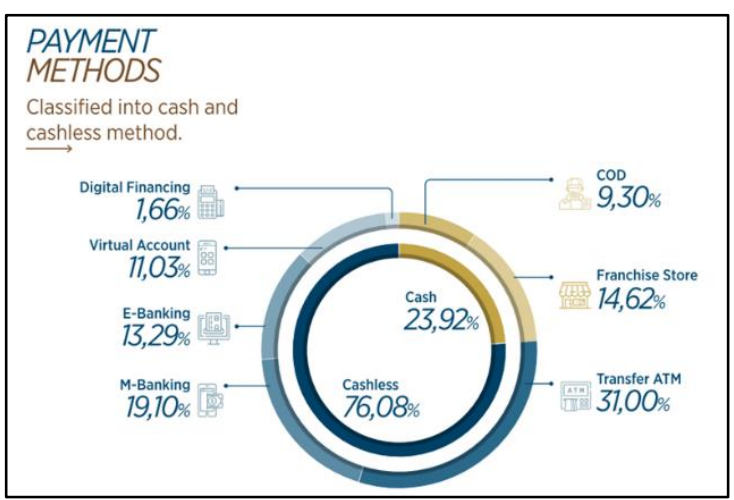

Figure 2. E-Commerce Payment Method in Indonesia (in \%)

Source: Katadata Insight Center (2018)

Even most Indonesian preferred to use the cashless model in settling their financial transaction, in fact most of them still relied on the digital banking system services, such as: virtual account (11.03\%), e-banking (13.29\%) and mobile banking (19.10\%). The digital financing itself had the lowest preference from the Indonesia customer (1.66\%).(Fintechnews, 2018; Katadata Insight Center, 2018). The latest report of characteristic of Indonesian customer behavior showed that $43.2 \%$ internet user never buy the products online (Indonesia Survey Center, 2020). Most of the customers who doing transaction online still preferred to pay COD (cash on delivery) after they received the ordered products.

The data indicated that customer are still reluctant in using the digital payment services because of the lack of financial literacy especially in digital services, less confidence in using the digital services because of the security concerns, less interested in using the digital payment because of the non-attractive features Meng (2016). Moons, et. al (2001) explained that personal innovativeness would create a curiosity in experimenting the digital payment services. Security concerns in terms of data privacy protection was the important consideration in using the digital services (Davis, 1992). Customers would have an enjoyable experience if they could feel that the platform could offer pleasant and fun experience. Finally, the higher personal innovativeness, security concerns and perceived enjoyment would develop customer trust in adopting the digital payment services (Schierz, Schilke, \& Wirtz, 2010).

The objective of the study was to know the effect of personal innovativeness, security concerns and perceived enjoyment into adoption of digital payment services using trust as mediating variable.

\section{Literature Review}

\subsection{Personal Innovativeness (PI)}

Personal Innovativeness is defined as the curiosity feeling of an individual in trying new technology (Agarwal \& Prasad, 1998). Individual who had a higher personal innovativeness would look for any information to fulfill the curiosity (Rouibah \& Abbas, 2010). Xu and Gupta (2019) also explained that personal innovativeness had a positive influence into prospective customers in trying new technology.

H1: Personal Innovativeness had a positive effect on customer trust.

\subsection{Security Concerns (SC)}

Each customer had an individual perception about the security concerns related in using the new technology (Abd Hamid, et.al, 2018) especially the potential negative in the processing usage of products and services, such as: free form hackers, secure payment services and data privacy protection. Khosravi \& Husein (2014) 
stated that individual less interested in adopting higher risk platform. High level of personal innovativeness would increase the higher curiosity, increase the confidence level, increase the willingness try new technology and finally will create the customer trust in adopting the new technology platform (Xu and Gupta, 2019). Customer decision to adopt and use the digital payment services is related with the customer concerns for safety protection of the digital payment services, which is measured by sufficient security to protect the user, safety transactional information and secured financing transaction (Egbunike, et.al, 2018). Lower risk platform would develop the customer trust easier (Chen, Lai \& Lin, 2014).

$\mathrm{H} 2$ : Security Concerns had a positive effect on customer trust.

\subsection{Perceived Enjoyment (PE)}

Perceived Enjoyment was an intrinsic motivation and defined as the perception that users will want to have in adopting the new technology (Davis et al., 1992). The customers were expected to have more enjoyable and fascinating experiences in using the platform (Deci et al., 1985). The higher level of enjoyment feeling and experience would increase the confidence level of the customers in acquiring the new technology (Moon and Kim, 2001). The highest confidence level was achieved if the new system was able to perform at the highest level (Teo, Lim and Lai, 1998). It is supposed to be fun to use the digital payment services if the platform had the interactive and attractive features. The psychological theories suggested by Deci et al. (1985) mention that individuals may engage in a particular behaviour because of its inherent enjoyment. The findings supported by the study of Moon et al's (2001) who stated that the individual curiosity, enjoyment, fun and pleasure feeling had a positive impact on the intention to use high technology.
H3: Perceived Enjoyment had an influence on trust.

\subsection{Trust (TR)}

Trust came if an individual had a comfortable and enjoyable feeling towards technology program (Abd Hamid, et.al, 2018; Li \& Huang, 2009). Trust defined as a secure feeling towards something (Schierz, Schilke \& Wirtz, 2010) and could be further classified as: belief, confidence, attitude, expectation about other parties' reliability and behavioural intention or behavioural of reliance that involved uncertainty (Li \& Huang, 2009). Trust was created if customers had an extensive knowledge about the benefit of the platform and how the business model was being able to solve the problem in settling the financial payment services (Meng, 2016). The customer trust was developing if the platform would be able to create curiosity in trying the new technology, give enjoyable experience and in the same time giving secure feeling or less risky in accessing the new technology (Chen, Lai \& Lin, 2014).

H4: Personal Innovativeness, Security Concerns and Perceived Enjoyment together had a significant influence to trust.

\subsection{Adoption of Digital Payment Services} (AD)

The adoption of the digital payment services was influenced by the individual's attitude, behavior and trust in using the digital payment services (Carpena et al., 2011). Lack of literacy and interested in the platform features or product services offered would create a reluctance decision in trusting to adopt the new technology (Bongomin et al., 2017). Trust able to create confidence level of the customers in using the new technology, reduce the uncertainty perception or risks of digital financing ( $\mathrm{Li}$ \& Huang, 2009), create enjoyable and positive feelings that finally would influence the customer adoption in using digital payment services (Meng, 2016). 
H5: Trust had a significant influence on customer adoption in using digital payment services.

Based on the explanation above, the research was being able to develop a theoretical framework below:

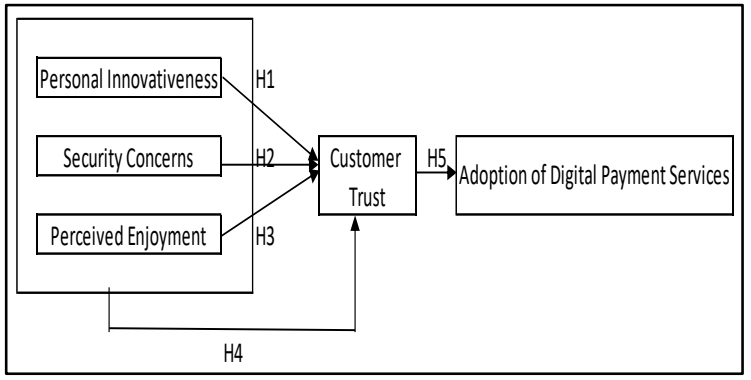

Figure 3. Proposed Research Framework

\section{Research Method}

As a quantitative study, this research is a descriptive research design with single cross-sectional data collection (Malhotra, Birks \& Wills, 2012). The purposive sampling method was used to know the sample that could be used as a research target. This study distributed 186 respondents to customers who used digital payment platform in settling their business transactions. The respondents were asked to answer close-ended questions with 1-5 Likert scale (Nunnaly, 1978). The Pearson correlation method was used to measure the correlation among indicators. Meanwhile, Cronbach's Alpha was used as reliability test and the Confirmatory Factor Analysis (CFA) was also used to measure the fitness of the research model. Furthermore, the analysis toward the structured model were used to see the correlation toward the latent variable. (Nunnaly, 1978).

The first part of the questionnaires consists with the demographic questions and the second part of the questionnaires consist with the research questions. All the primary data further tested statistically using Structural Equation Model with Lisrel 8.80 software.
The personal innovativeness (PI) was measured by three indicators, namely: the experiment of using new technology (PI1); the first explorer among peers in trying new technology (PI2) and the level of curiosity in adopting technology (PI3) (Agarwal et al.,1998). The security concerns (SC) was measured also by three indicators, included: secure feeling (SC1), protective information (SC2), data privacy from hackers (SC3) (Gupta et al., 2010).

The perceived enjoyment (PE) was measured by four indicators, such as: fun feeling (PE1), pleasant feeling (PE2), enjoyable experience (PE3) and interactive or interesting activities (PE4) (Davis, 1992). The trust variable (TR) was measured by clearly conception of the functionality about the system (TR1), the system provider is well widely acknowledged (TR2) and the ability of the system to protects the privacy and data user (TR3) (Meng, 2016). The adoption decision in using the digital payment services would be measured by three indicators, namely: the planning to use in the future (AD1), the intention to use in the future (AD2) and the prediction of would use the digital payment services in the future (AD3) (Venkatesh et al., 2012).

\section{Result and Discussion}

Demographic data explained the profile of the respondents; $50.2 \%$ respondents were female with the majority age being 17-30 years old $(53 \%)$. Most of them $(64 \%)$ were university graduates and worked as employees (53\%). 68\% of respondents had an average monthly expenditure of 5 Million Rupiah (68\%) with only $41.4 \%$ of them using the digital payment services for the financial transaction less than five hundred thousand rupiahs. OVO was the most favorite platform of digital payment services (46\%), followed by GOPAY (38\%), Link Aja (8\%), Dana (5\%) and Shopee Pay (3\%). Major financial transaction the respondents done were buying online $(79 \%)$. The motivation of 
using the digital payment services because of the cheapest price $(15.2 \%)$; easily access $(13.2 \%) ;$ speedy, simple and practical (10.3\%); promotion (8.3\%) and Covid reason $(0.1 \%) .12 .9 \%$ respondents found difficulties in using the digital payment due to the lack of familiarity in using the platform (68.9\%). Using Pearson correlation method and pre-test, it found that the critical value of $t>0.691$, showed that all indicators had strong correlation. Reliability test using Cronbach's Alpha coefficient showed the number of 0.911 , which meant that this research is valid (Nunnaly, 1978). To measure the fitness of the research model, the Confirmatory Factor Analysis (CFA) was used. Analysis toward the structured model were used to see the correlation toward the latent variable. The table 1 showed that all GOF indicator had a good fit model and there were perfect theories in this research. Meanwhile, the table 2 showed the value of R Square and Adjusted R Square for each variable, in which Trust variable had the highest value of $\mathrm{R}$ square 0.745 and Personal Innovativeness had the lowest R square of 0.263 . It meant that $74.5 \%$ trust variable was influenced by the variable of personal innovativeness, security concerns and perceived enjoyment with the $25.5 \%$ was influenced by other variables.

Table 1. Design Summary for Goodness for Fit Testing Model

Source: Data Analysis using LISREL 8.80 (2020)

\begin{tabular}{lccl}
\hline $\begin{array}{c}\text { GOF } \\
\text { Indicator }\end{array}$ & Est.Value & $\begin{array}{c}\text { Testing } \\
\text { Result }\end{array}$ & Conclusion \\
\hline Absolute Fit Value & & \\
GFI & GFI $\geq 0.90$ & 0.94 & Good Fit \\
RMSEA & RMSEA $<0.08$ & 0.06 & Good Fit \\
\hline & Incremental Fit Value & & \\
NNFI & NNFI $>0.90$ & 0.91 & Good Fit \\
NFI & NFI $>0.90$ & 0.99 & Good Fit \\
AGFI & AGFI $>0.90$ & 0.93 & Good Fit \\
RFI & RFI $>0.90$ & 0.98 & Good Fit \\
IFI & IFI $>0.90$ & 0.97 & Good Fit \\
\hline
\end{tabular}

Table 2. R-Square and Adjusted R-Square Source: Data Analysis using LISREL 8.80 (2020)

\begin{tabular}{lll}
\hline Variables & R-Square & $\begin{array}{l}\text { Adjusted } \\
\text { R-Square }\end{array}$ \\
\hline Personal Innovativeness & 0.263 & 0.131 \\
Security Concerns & 0.561 & 0.583 \\
Perceived Enjoyment & 0.432 & 0.233 \\
Trust & 0.745 & 0.883 \\
\hline
\end{tabular}

Meanwhile, the result of hypotheses testing using path diagram, could be explained as follow:

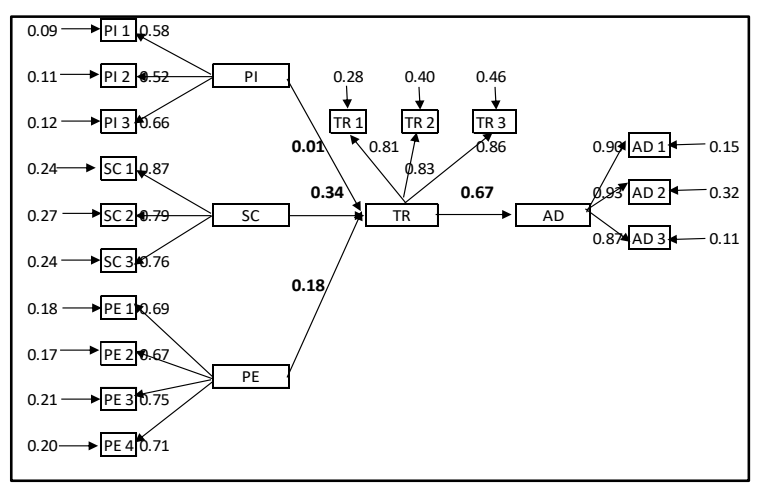

Figure 4. Structural Diagram (Standardized)

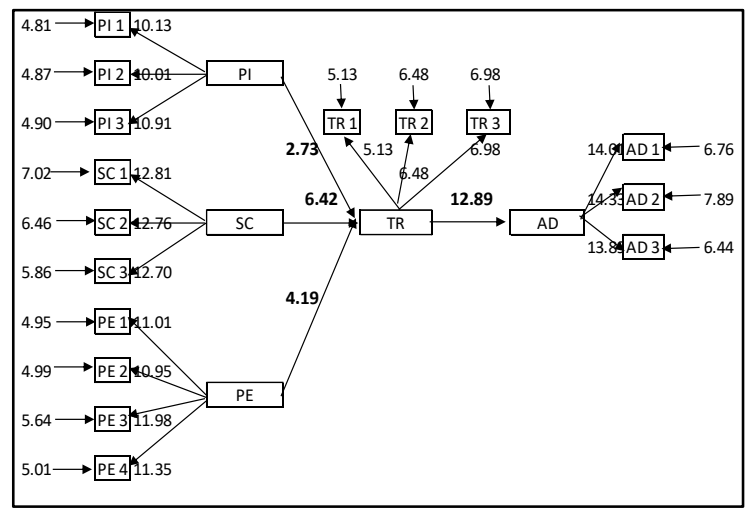

Figure 5. Structural Diagram (t-value)

The result of hypotheses testing could be explained below:

Table 3. Result of Hypothesis Testing Source: Data Analysis using LISREL 8.80 (2020)

\begin{tabular}{lllll}
\hline $\begin{array}{c}\text { Hypo- } \\
\text { theses }\end{array}$ & Variables & \multicolumn{2}{c}{$\begin{array}{c}\text { Coefficient } \\
\text { Standard }\end{array}$} & $\begin{array}{c}\text { Stalistical } \\
\text { Conclusion }\end{array}$ \\
\hline $\mathrm{H}_{1}$ & $\mathrm{PI} \rightarrow \mathrm{TR}$ & 0.01 & 2.73 & Data Supported \\
$\mathrm{H}_{2}$ & $\mathrm{SC} \rightarrow \mathrm{TR}$ & 0.34 & 6.42 & Data Supported \\
$\mathrm{H}_{3}$ & $\mathrm{PE} \rightarrow \mathrm{TR}$ & 0.18 & 4.19 & Data Supported \\
$\mathrm{H}_{4}$ & $\mathrm{PI}, \mathrm{SC}, \mathrm{PE} \rightarrow \mathrm{TR}$ & 0.54 & 7.84 & Data Supported \\
$\mathrm{H}_{5}$ & $\mathrm{TR} \rightarrow \mathrm{AD}$ & 0.67 & 12.89 & Data Supported \\
\hline
\end{tabular}


The research able to create a structural equation model as follow:

$$
\begin{aligned}
& \mathrm{TR}=0.01 * \mathrm{PI}+0.34 * \mathrm{SC}+0.18 * \mathrm{PE} \\
& \begin{array}{lll}
(0.054) \quad(0.050) \quad(0.043)
\end{array} \\
& 2.73 \quad 6.42 \quad 4.19 \\
& \text { Errorvar. }=0.43, \mathrm{R}^{2}=0.563 \\
& \mathrm{AD}=0.67 * \mathrm{TR} \\
& \text { (0.56) } \\
& \text { (12.89) } \\
& \text { Errorvar. }=0.43, \mathrm{R}^{2}=0.745
\end{aligned}
$$

The result of hypotheses testing could be explained further:

$\mathrm{H}_{1}$ : Personal innovativeness had a positive effect on customer trust, with the t-value > $2(2.73>2)$, with the effect value of 0.01 .

The finding was aligned with the previous research conducted by Rouibah \& Abbas (2010) who stated that personal innovativeness had statistically significant toward trust. The research showed that the customers decision to adopt the digital payment services if the platform were able to fulfill their curiosity of the features and services offered. This finding supported the previous research done by $\mathrm{Xu}$ and Gupta (2019) who mentioned that the customer who were satisfied in their first experiment in exploring the new digital payment platform tend to continue adopting that platform.

$\mathrm{H}_{2}$ : Security concerns had a positive effect on customer trust, with the t-value of 6.42 and the effect value of 0.34 .

The result supported the previous research that mentioned that security concerns had the highest significant effect into trust (li \& Huang, 2009). Some risks related with the digital payment services data security and protection privacy the finding also supported the research done by Dorfleitner et al. (2017) who explained the secure platform would keep the secrecy of the customer's data information. If the customers felt secure in that platform, they are willing to adopt and use it in making payment services (Gupta et al., 2010).

$\mathrm{H}_{3}$ : Perceived Enjoyment had an influence on trust, with the t-value of 4.19 and the effect value of 0.18 .

If users found difficulties in accessing the digital platform, it would also influence their reluctant behaviour in adapting the new technology (Egbunike, et.al, 2018). The result of this research also aligned with the previous study of Chen, Lai, \& Lin (2014) who explained that one key success factor for the fintech platform to attract the users was the ability to provide the user interface (UI) and user experience design (UX). The customers are willing to adopt the digital payment services if they had enjoyable experience, fun and pleasant feeling, enjoyable experience that is supported with the modern and interactive features (Deci et al., 1985).

$\mathrm{H}_{4}$ : Personal Innovativeness, Security Concerns and Perceived Enjoyment together had a significant influence to trust, with the t-value of 7.84 and the effect value of 0.54 .

This study found that the customers trust in adopting the new digital payment services if they felt secure, had an enjoyable experience when access the digital payment services for the first time. Therefore, the study supported with the study of Venkatesh et al. (2012).

H5: Trust had the highest and significant influence on customer decision to borrow for ultra-micro segments in Indonesia's P2P lending platforms, with the t-value of 12.89 and the effect value of 0.67 .

The finding supported the previous study that mentioned trust as the major factor in creating customer perception Egbunike (2018). The customer preferred to choose the platform that had positive credibility in public image Walchek (2015). Customer 
preferred to do business with the authorized digital payment services. In Indonesia, the digital payment services had to registered and got the license from the government body (OJK). The study aligned with the research result from (Zhang, et.al, 2017) who stated that every business organization must meet and follow with the government regulation.

\section{Conclusion \& Suggested Further Research}

Trust had the highest effect in influencing customer decision to adopt the digital payment services. Meanwhile, all the variables such as personal innovativeness, security concerns and perceived enjoyment had positive impact in developing the borrower trust, in which the security concerns had the highest effect. The application platform should develop innovation that focus more on user-friendly features and experiences using more understandable languages and symbols. The $\mathrm{R}$-square of this research showed the value of 0.745. It meant that even trust had a positive impact in customer decision to borrow with $74.5 \%$ effect, there might be other variables that could be considered in influencing trust, such as: customer knowledge and financial literacy. But, there're an urgency to encourage the support of the technology financial ecosystem, including the government in initiating a clear regulation to protect the customers interest and in the same time had to deliver highest standard of service quality to attain firm competitiveness and performance since the customers are more interested with more attractive offers and services.

Acknowledgements. The author would like to thank to Direktorat Riset dan Pengabdian Masyarakat, Direktorat Jendral Penguatan Riset dan Pengembangan dan Kementrian Riset, Teknologi dan Pendidikan Tinggi according to Research Contract Number: 1575/HD/LPPM-UMN/IV/2020 that has given financial support in this research.

\section{References}

Abd Hamid, N., Kurniasari, F., Hakimah, A.M.T., Fairuz, T.E., Nor, H.M.S., Morazah, M.A., Nurshamimi, S. (2018). A comparative study of Malaysian and Indonesian students' entrepreneurial characteristics and career choices resulting from the digital economy. International Journal of Supply Chain Management, 7(5), pp. 250-258.

Agarwal, R \& Prasad, J (1998). A conceptual and operational definition of personal innovativeness in the domain of information technology. Information Systems Research, 9(2), https://doi.org/10.1287/isre.9.2.204

Bongomin, G. O. C., Munene, J. C., Ntayi, J. M., \& Malinga, C. A. (2017). Financial literacy in emerging economies: Do all components matter for financial inclusion of poor households in rural Uganda? Managerial Finance, 43(12), pp. 1310-1331. https://doi.org/10.1108 /MF-04-2017-0117

Carpena, F., Cole, S., Shapiro, J., \& Zia, B. (2011). Unpacking the causal chain of financial literacy. The World Bank Development Research Group, September, pp. 1-36.

Chen, D., Lai, F., \& Lin, Z. (2014). A trust model for online peer-to-peer lending: a lender's perspective. Information Technology Management 5(4), pp. 239-254.

Daily Social. (2018). Fintech Report 2018 (Issue 22613).

Davis, et. al (1992). Extrinsic and intrinsic motivation to use computers in the workplace. Journal of Applied Social Psychology, 22(14), pp. 1111-1132. https://doi.org/10.1111/j.1559-1816. 1992.tb00945.x. 
Deci, et. al (1985). Intrinsic Motivation And Self-determination in Human Behavior: Perspectives in Social Psychology. Springer.

Dorfleitner, G., Hornuf, L., Schmitt, M., \& Weber, M. (2017). FinTech in Germany. FinTech in Germany, 1121. https://doi.org/10.1007/978-3319-54666-7.

Egbunike, F.C., Emudainohwo, O.B., Gunardi, A., Kurniasari, F., Prihanto, J.J.N. (2018). Sustainability accounting practices and disclosure by multinational corporation in Nigeria. Journal of Applied Economic Sciences XIII Summer, 3(57), pp. 751759.

Fintechnews. (2018). Indonesia: Fintech Landscape Repot (Issue May).

Indonesia Survey Center (2020). Laporan Survei Internet Asosiasi Penyelenggara Jasa Internet Indonesia (2019-2020 Q2).

Katadata Insight Center. (2018). Indonesia e-commerce mapping 20189.9. Katadata Insight Center. pp. 1-12.

Khosravi and Hussin (2014). A review of customer knowledge management importance. Journal of Soft Computing and Decision Support Systems, 1(1), pp. 45-52.

Li, Y., \& Huang, J. (2009). Applying theory of perceived risk and technology acceptance model in the online shopping channel. World Academy of Science, Engineering and Technology, pp. 9-12

Malhotra, B., \& Wills (2012). Marketing Research (4th ed.). pp. 76-78.

Meng, F. (2016). What Determinants of Lending Decision for Chinese peerto-peer lenders? Profile of Finance Management, pp. 92-93
Moon \& Kim (2001). Extending the TAM for a world-wide-web context. Information \& Management, 38(4), pp. 217-230. DOI: $10.1016 / \mathrm{S} 0378-$ 7206(00)00061-6.

Nunnaly, J. (1978). Psychometric Theory. McGraw-Hill, pp. 64-65.

Rouibah, K \& Abbas, H (2011). Factors affecting camera mobile phone adoption before e-shopping in the Arab world. Technology in Society, 33(3), DOI: 10.1016/j.techsoc.2011 .10 .001 .

Schierz, P., Schilke, O., \& Wirtz, B. (2010). Understanding consumer acceptance of mobile payment services: An empirical analysis. Electronic Commerce Research and Applications, 9(3), pp. 209-216.

Teo, T.S.H., Lim, V.K.G., Lai, R.Y.C. (1999). Intrinsic and extrinsic motivation in Internet usage. Omega 27(1). pp. 25-37. https://doi.org/10. 1016/S0305-0483(98) 00028-0

Venkatesh, V.; Bala, H. (2009). Technology acceptance model 3 and a research agenda on interventions. Decision Sciences, 39(2), pp. 273315.

Walchek, S. (2015). The unbundling of finance. Tech-Crunch, pp. 3-9.

We Are Social \& Hootsuite. (2020). Digital Data Indonesia 2020, pp. 1-97. https://datareportal.com/reports/digit al-2020-Indonesia.

Xu \& Gupta (2009). The effects of privacy concern and personal innovativeness on potential and experienced customers' adoption of location-based services. Electron Markets, 19, pp. 137-149. DOI 10.1007/s12525-0090012-4. 
Zhang, Y., Li, H., Hai, M., Li, J., \& Li, A. (2017). Determinants of loan funded successful in online P2P lending, information technology and quantitative management. Advances in Economics and Business, 5, pp. 11-17. 